\title{
Studi Kasus Penanganan Kesulitan Membaca Siswa ABK Kelas 3 SD Negeri Poncol 03 Pekalongan dengan Metode Struktural Analitik Sintetik (SAS)
}

\author{
${ }^{*}$ Nur Ba'diah Maulida ${ }^{1}$, Khusnul Fajriyah ${ }^{2}$, Muhammad Arief Budiman Yeni ${ }^{3}$
}

1,2,3 Jurusan Pendidikan Guru Sekolah Dasar, Universitas PGRI Semarang, Semarang, Indonesia

\section{A R T I C L E I N F O}

\section{Article history:}

Received 15 August 2019 Received in revised form 20 September 2019 Accepted 10 October 2019 Available online 30November 2019

\section{Kata Kunci:}

struktural analitik sintetik, $A B K$

Keywords: synthetic analytical structural, $A B K$

\begin{abstract}
A B S T R A K
Bahasa ialah suatu hal yang penting dalam berkomunikasi di kehidupan. Dalam mengajarkan sebuah bahasa khususnya bagi seorang anak tunagrahita sedang, sangatlah perlu dibuat sebuah rencana yang matang serta sistematis berdasarkan karakteristik anak. hasil belajar mata pelajaran bahasa Indonesia kelas 3 tersebut masih rendah, terutama pada kemampuan membaca. Penelitian ini bertujuan untuk mengetahui perbedaan keterampilan membaca sebelum menggunakan metode Strutural Analitik Sintetik (SAS) dan setelah menggunakan metode Struktural Analitik Sintetik (SAS) pada siswa ABK kelas 3 SD. Jenis penelitian ini menggunakan penelitian desriptif kualitatif. Populasi dari penelitian ini adalah siswa ABK kelas 3 SD yang berjumlah 3 orang. Data yang dikumpulkan dalam penelitian ini diperoleh dari hasil observasi keteramoilan membaca dengan instrumen lembar pengamatan. Data yang diperoleh dianalisis secara deskriptif. Dengan hasil menunjukan bahwa terdapat perbedaan keterampilan membaca sebelum menggunaan metode Struktural Analiti Sintetik (SAS) memperoleh hasil rata-rata ketiga siswa ABK yaitu $33,33 \%$ dan
\end{abstract} sesudah menggunakan metode Struktural Analiti Sintetik (SAS) memperoleh hasil dari masing-masing pertemuan siswa $A B K$ yaitu pertemuan pertama $41,66 \%$, pertemuan kedua $45,13 \%$, pertemuan ketiga $52,77 \%$. Hal ini menunjukan ada pengaruh positif dari metode Struktural Analitik Sintetik (SAS) terhadap keterampilan membaca siswa ABK dibandingkan tidak menggunakan metode Struktural Analitik Sintetik (SAS).

\begin{abstract}
A B S T R A C T
This study aims to determine the differences in reading skills before using the Synthetic Analytical Strutural (SAS) method and after using the Synthetic Analytical Structural (SAS) method in class 3 students with special needs in Poncol 03 State Elementary School, Pekalongan. This type of research uses descriptive qualitative research. The population of this research is the 3rd grade students of $A B K$ Poncol 03 Pekalongan, totaling 3 people. Data collected in this study were obtained from observations of reading ability with an observation sheet instrument. The data obtained were analyzed descriptively. With the results showing that there are differences in reading skills before using the Synthetic Analytical Structural (SAS) method, the average yield of three students with special needs is $33.33 \%$ and after using the Synthetic Structural Analytical (SAS) method, the results of each meeting students with special needs are: the first meeting $41.66 \%$, the second meeting $45.13 \%$, the third meeting $52.77 \%$. This shows that there is a positive influence on the method of Synthetic Analytical Structural (SAS) on the reading skills of students with special needs compared to not using the method of Synthetic Analytical Structural (SAS).
\end{abstract}





\section{Pendahuluan}

Amanah pendidikan untuk semua (PUS) yang termakrub dalam Deklarasi Universal Hak Asasi Manusia 1948 menegaskan bahwa "Setiap orang mempunyai hak atas pendidikan". Pernyataan ini selaras dengan jiwa pasal 31 UUD 1945 tentang hak setiap warga Negara untuk memperoleh pendidikan dan pasal 32 UUSPN No 20 Tahun 2003 tentang Pedidikan dan Layanan Khusus. Gerakan PUS yang realisasinya adalah memberikan kesempatan belajar bagi anak berkebutuhan khusus juga dilandasi pernyataan Salamanca pada tahun 2004 tentang pendidikan inklusi. Pendidikan inklusi bertujuan untuk memungkinkan siswa meraih potensi mereka (Marilyn Friend \& William D. Bursuck, 2015:5). Sesuai dengan amanat Undang-Undang Dasar 1945 pasal 31 ayat 1 dan Undang-Undang Nomor 20 Tahun 2003 tentang sistem pendidikan Nasional Bab 2 IV pasal 5 ayat 1 dinyatakan bahwa setiap warga Negara mempunyai kesempatan yang sama dalam memperoleh pendidikan yang bermutu, dalam hal ini termasuk di dalamnya adalah anak yang berkebutuhan khusus $(A B K)$, sistem pendidikan inklusi memberikan kesempatan belajar pada anak-anak berkebutuhan khusus bersama dengan anak-anak pada umumnya, sehingga mereka dapat menyesuaikan diri dengan kehidupan nyata sehari-hari. Menurut pasal 32 ayat (1) bahwa pendidikan khusus merupakan pendidikan bagi peserta didik yang memiliki tingkat kesulitan dalam mengikuti proses pembelajaran karena karakteristik fisik, emosional, mental, sosial, dan / atau memiliki potensi kecerdasan dan bakat istimewa yang berbeda dengan anak-anak lainnya. Melihat situasi sekarang ini banyak anak berkebutuhan khusus yang dapat mengenal bangku sekolah di sekolah regular berserta anak-anak yang memiliki kemampuan diatasnya, namun dalam proses pembelajaran anak yang memiliki kebutuhan khusus cenderung tertinggal dan diam tanpa memperhatikan penjelasan dari guru. Situasi ini sesuai dengan kondisi lapangan di SD Negeri Poncol 03 Pekalongan berdasarkan pengajaran bahasa Indonesia, ada 3 orang siswa yang kemampuan membacanya tidak lancar, ketidaklancaran membaca akan berdampak pada kegagalan anak dalam menguasai area akademik lainnya (Chall, 1990) dan kegagalan tersebut akan semakin parah seiring dengan naiknya jenjang kelas anak yang bersangkutan. Kemampuan membaca dibangun berdasarkan keterampilan yang telah dikuasai sebelumnya.

Berdasarkan Standar Kompetensi dan Kompetensi Dasar Tingkat SD/MI dalam Peraturan Meteri Pendidikan Nomor 22 Tahun 2006 tentang standar isi untuk satuan pendidikan dasar dan menengah bahwa standar kompetensi bahasa Indonesia merupakan kualifikasi kemampuan minimal perserta didik yang menggambarkan penugasan, pengetahuan, keterampilan berbahasa, dan sikap positif terhadap bahasa dan sastra Indonesia. Standar kompetensi ini merupakan dasar bagi peserta didik memahami dan merespon situasi lokal, regional, national, dan global.

Depdiknas merumuskan Kompetensi Dasar untuk mencapai target tujuan mata pelajaran bahasa Indonesia SD dan MI, adalah sebagai berikut: "(1) menyimak; (2) berbicara; (3) membaca; dan (4) menulis". Keterampilan membaca sebagai salah satu dari empat keterampilan berbahasa mempunyai peran yang sangat penting di dalam kehidupan manusia. Guru kelas memegang peranan penting dalam bidang pembelajaran bahasa Indonesia khususnya membaca. Tanpa memiliki kemampuan membaca yang memadai sejak dini maka anak akan mengalami kesulitan belajar pada kemudian hari. Kemampuan membaca menjadi dasar yang utama tidak hanya bagi pengajaran bahasa Indonesia sendiri, akan tetapi juga bagi pengajaran mata pelajaran lain.

(Tarigan, 2008) Keterampilan berbahasa dalam kurikulum di sekolah biasanya mencakup empat komponen yaitu keterampilan menyimak, berbicara, membaca, dan menulis. Biasanya melalui suatu hubungan yang teratur. Mula-mula, pada masa kecil kita belajar menyimak bahasa kemudian berbicara, sesudah itu bisa belajar membaca dan menulis.

Keempat keterampilan berbahasa di atas (menyimak, berbicara, membaca, dan menulis) perlu diajarkan pada anak-anak baik anak normal maupun ABK. Dalam pengajarannya guru harus kreatif, sehingga kegiatan belajar mengajar tidak membosankan dan tujuan pembelajaran bisa tercapai. Keefektifan guru bisa dengan cara menggunakan berbagai jenis model pembelajaran salah satu model pembelajaran yang bisa diterapkan dalam pembelajaran keterampilan berbahasa (khusunya membaca) adalah model pair checks (Resmi, 2019)

(Ningrat \& Sumantri, 2018) Bahasa ialah suatu hal yang penting dalam berkomunikasi di kehidupan. Dalam mengajarkan sebuah bahasa khususnya bagi seorang anak tunagrahita sedang, sangatlah perlu dibuat sebuah rencana yang matang serta sistematis berdasarkan karakteristik anak. Bahasa memiliki peran yang vital dalam perkembangan kemampuan sosial, kognitif, akademik anak (Nation \& Snowling 2004; Girrut, 2004; Eikeseth \& Nesset, 2003). Fakta di lapangan mendukung bahwa anak yang mengalami hambatan berbahasa dan kesulitan belajar mempunyai efek negatife dan signifikan pada pendidikan anak (Hurt \& Mashall, 1994). 
Berdasarkan observasi di SD Negeri Poncol 03 Pekalongan hasil belajar mata pelajaran bahasa Indonesia kelas 3 tersebut masih rendah, terutama pada kemampuan membaca. Hal ini terbukti dengan rendahnya nilai UTS bahasa Indonesia. Dari 28 jumlah siswa terdapat tiga orang siswa yang belum tuntas KKM, namun ketiga siswa tersebut merupakan siswa berkebutuhan khusus.

Berdasarkan hasil wawancara guru kelas 3, belum tercapainya nilai KKM terjadi karena dalam pembelajaran bahasa Indonesia siswa mengalami kesulitan terutama pada keterampilan membaca, disamping itu juga siswa yang belum tuntas KKM merupakan siswa berkebutuhan khusus. Dari hasil nilai UTS tiga siswa tersebut hanya mendapat nilai 20, 30, 30 dari nilai KKM 70. Ketidak tuntasan nilai ulangan tengah semester tersebut karena tiga siswa tersebut memiliki kesulitan dalam belajar terutama pada keterampilan membaca. Pada keterampilan membaca ketiga siswa tesebut sangat rendah, bahkan salah satu diantara tiga siswa tersebut belum dapat menggabungkan huruf-huruf menjadi suku kata. Apabila dillihat dari segi usia, seharusnya anak seusia kelas 3 SD harus sudah bisa bahkan lancar dalam membaca tanpa harus mengeja setiap suku kata. Namun pada kasus yang dialami tiga siswa tersebut berbeda dengan siswa lainnya, tiga siswa tersebut memiliki skor IQ 80-89, 60-70, 80-89 dengan arti lain siswa tersebut dapat dikatakan memiliki IQ rata-rata lamban, lamban, dan rata-rata lamban.

Rendahnya kemampuan siswa dalam berbahasa Indonesia disadari oleh guru kelas 3 bahwa permasalahan tersebut sedikit banyaknya menghambat proses pembelajaran di semua mata pelajaran. Guru harus mengartikan setiap kata yang tidak dimengerti oleh siswa. Oleh karena itu peneliti mengambil fokus permasalahan keterampilan siswa dalam membaca.

Berdasarkan hasil pengamatan peneliti, keterampilan membaca masih kurang. Permasalahan tersebut disebabkan oleh siswa memiliki kebutuhan khusus sehingga susah membaca kata atau soal yang diberikan oleh guru kelas. Siswa yang memiliki kebutuhan khusus cenderung tidak mau aktif dalam pembelajaran di kelas, siswa tersebut mengganggu temannya sehingga merusak konsentrasi siswa lain. Namun kenyataannya dilapangan ditemukan banyak siswa tidak lancar membaa, padahal siswa dituntut untuk bisa membaca sebagai acuan untuk memperoleh hasil saat tes ujian semester.

Peneliti menemukan suatu permasalahan yang terjadi pada siswa ketika peneliti melakukan Observasi di SD N Poncol 03 Pekalongan. Permasalahan yang ditemukan oleh peneliti yaitu ada beberapa siswa yang memiliki masalah dalam membaca yang mengakibatkan proses belajar terganggu. Siswa yang tidak lancar dalam membaca menjadi sering tertinggal dalam proses pembelajaran.

Proses belajar yang terganggu berkaitan dengan perkembangan kognitif siswa. Siswa satu dengan yang lain memiliki perkembangan kognitif yang berbeda-beda. Gagne dalam (Jamaris, 2014) mengatakan kognitif adalah proses yang terjadi secara internal di dalam pusat susuan syaraf pada waktu manusia sedang berfikir. Dalam hal ini peneliti akan melakukan penelitian dengan menggunakan salah satu metode dalam pembelajaran keterampilan membaca adalah structural analitik sintetik (SAS).

(Lisnawati \& Muthmainah, 2018) Metode SAS adalah suatu metode yang diawali secara keseluruhan yang kemudian dari keseluruhan itu dicari dan ditemukan bagian-bagian tertentu dan fungsifungsi bagian itu. Setelah mengenal bagian-bagian serta fungsinya kemudian dikembangkan pada struktur totalitas seperti penglihatan semula. Metode SAS dapat merangsang anak didik untuk melibatkan diri secara aktif, karena anak didik selain mendengarkan, melafalkan, dan mencatat, juga mempergunakan alat peraga. (Eliastuti \& Irwansyah, 2018) SAS mempunyai langkahlangkah dengan urutan sebagai berikut: (a) strukutur, menampilkan keseluruhan, (b) analisis, melakukan proses penguraian, (c) sintesis, melakukan penggabungan kembali pada struktur semula. Metode SAS merupakan metode yang dikhususkan untuk belajar membaca dan menulis permulaan di SD, meskipun demikian metode SAS dapat dipergunakan dalam berbagai bidang pengajaran. (Kurniasih, 2017) Menerangkan bahwa metode SAS yaitu metode pembelajaran membaca permulaan yang melalui beberapa tahap: struktural menampilkan keseluruhan dan memperkenalkan sebuah kalimat utuh; analitik melakukan proses penguaraian; sintetik melakukan penggabungan kembali ke bentuk struktural semula. Penggunaan metode SAS sangat tepat bagi siswa yang belum bisa membaca karena metode SAS sudah teruji. Berdasarkan hasil survei lapangan di SD Negeri Poncol 03 Pekalongan dan berdasarkan arahan guru kelas tiga, peneliti menggunakan metode SAS yang sangat cocok diterapkan pada siswa saat pembelajaran bahasa Indonesia. Berdasarkan uraian tersebut, maka perlu dilakukan penelitian dengan judul "studi kasus penanganan kesulitan membaca siswa ABK kelas 3 SD Negeri Poncol 03 Pekalongan dengan metode struktural analitik sintetik (SAS).

\section{Metode}

Jenis penelitian ini menggunakan kualitatif diskriptif degan menguraikan fakta0faka atau dat-data yang diperoleh dari sumber data. Dari data itu emudian dianalisis sesuan dengan pembelajaran bahasa Indonesia. Populasi dalam penelitian ini adalah siswa ABK kelas 3 SD Negeri Poncol 03 Pekalongan. 
Banyaknya anggota populasi dalam penelitian ini adalah 3 orang siswa ABK. Penelitian ini menyelidiki pengaruh metode Stuktural Analitik Sintetik dengan menggunakan media hartu huruf.

Metode pengumpulan data menggunakan tes dan non tes. Teknik tes untuk mengukur pemahaman kemampuan membaca siswa ABK dan teknik non tes untuk mendapatkan informasi dari observasi guru dan siswa $\mathrm{ABK}$, angket atau kuesioner siswa $\mathrm{ABK}$, wawancara guru dan orang tua siswa $\mathrm{ABK}$.

\section{Hasil dan Pembahasan}

Berdasarkan data hasil angket siswa ABK termasuk kategori baik. Hal tersebut dibuktikan dengan data angket yang diisi siswa ABK dengan bantuan guru dengan hasil perhitungan pada tabel 1 berikut.

Tabel 1. Tabulasi Data Angket Siswa

\begin{tabular}{lc}
\multicolumn{1}{c}{ Responden } & Jumlah skor dari hasil angket \\
\hline Responden I & 33 \\
Responden II & 30 \\
Responden III & 31 \\
\hline \multicolumn{1}{c}{ Jumlah } & $\mathbf{9 4}$ \\
\hline
\end{tabular}

Jumlah skor (apabila jumlah butir soal =38) x (jumlah responden $=3$ ) adalah 114. Dengan demikian jika jumlah hasil pengumpulan data 114 ditinjau dari empat aspek menurut tiga responden yaitu 94 : 114 x 100\% = 82,4\% . dari kriterium yang ditetapkan apabila nilai 82,4\% masuk pada kategori sangat baik. Dengan nilai pengkategorian nilai presentase angket pada tabel 2 berikut.

Tabel 2. Nilai Presentasi Angket Siswa

\begin{tabular}{lc}
\hline \multicolumn{1}{c}{ Keterangan } & Nilai \\
\hline Sangat Baik & $76 \%-100 \%$ \\
Baik & $51 \%-75 \%$ \\
Kurang Baik & $26 \%-50 \%$ \\
Tidak Baik & $1 \%-25 \%$ \\
\hline
\end{tabular}

Berdasarkan hasil pembelajaran kelas dengan penelitian kemampuan membaca dapat diketahui bahwa tiga siswa $(40,00 \%)$ tidak mencapai KKM sedangkan 26 siswa (83,07\%) nilainya memenuhi KKM, dengan rata-rata kelas diperoleh 78,62\% dari pembelajaran bahasa Indonesia.

Untuk proses penilaian keterampilan dan mengetahui perkembangan kemampuan membaca siswa guru mengambil data pada saat siswa membaca satu per satu khusunya pada siswa ABK. Dengan nilai keterampilan membaca ditunjukkan pada 3 berikut.

Tabel 3. Hasil Penilaian Keterampilan Membaca Siswa ABK

\begin{tabular}{cccccccccc}
\hline \multirow{2}{*}{ No. } & & Skor RA & & \multicolumn{3}{c}{ Skor RB } & \multicolumn{3}{c}{ Skor RC } \\
\cline { 2 - 9 } & P 1 & P 2 & P 3 & P 1 & P 2 & P 3 & P 1 & P 2 & P 3 \\
1 & 1 & 2 & 2 & 2 & 2 & 3 & 2 & 3 & 3 \\
2 & 1 & 1 & 2 & 2 & 2 & 3 & 2 & 3 & 3 \\
3 & 1 & 1 & 2 & 2 & 2 & 3 & 2 & 3 & 3 \\
4 & 1 & 1 & 2 & 2 & 2 & 3 & 2 & 3 & 3 \\
5 & 1 & 1 & 1 & 2 & 2 & 2 & 2 & 2 & 3 \\
6 & 1 & 1 & 1 & 2 & 2 & 2 & 2 & 2 & 3 \\
7 & 1 & 1 & 1 & 2 & 2 & 2 & 2 & 2 & 3 \\
8 & 1 & 1 & 1 & 2 & 2 & 2 & 2 & 2 & 3 \\
9 & 1 & 1 & 1 & 2 & 2 & 2 & 2 & 2 & 2 \\
10 & 1 & 1 & 1 & 2 & 2 & 2 & 2 & 2 & 2 \\
11 & 1 & 1 & 1 & 2 & 2 & 2 & 2 & 2 & 2 \\
12 & 1 & 1 & 1 & 2 & 2 & 2 & 2 & 2 & 2 \\
\hline Jumlah & $\mathbf{1 2}$ & $\mathbf{1 3}$ & $\mathbf{1 6}$ & $\mathbf{2 4}$ & $\mathbf{2 4}$ & $\mathbf{2 8}$ & $\mathbf{2 4}$ & $\mathbf{2 8}$ & $\mathbf{3 2}$ \\
\hline
\end{tabular}


Pada pertemuan pertama skor presentase perolehan keterampilan membaca responden I, (jika nilai tertinggi setiap butir $=4) \times($ jumlah total keseluruhan butir pertanyaan $=12) \times($ jumlah responden $=$ 3) adalah 144. Jika jumlah total hasil pengumpulan data 144 maka hasil presentasi pembelajaran bahasa Indonesia pertemuan I yaitu $12: 144 \times 100 \%=08,33 \%$. Pada pertemuan kedua responden I memeproleh hasil presentase $09.02 \%$, kemudian pada pertemuan ketiga responden I mengalami kenaikkan kemampuan membaca dengan hasil presentase $11,11 \%$.

Kemudian hasil pemorolehan nilai keterampilan membaca responden II pada pertemuan pertama mendapat skor presentase perolehan perhitungan dari $24: 144 \times 100 \%=16,66 \%$. Pada pertemuan kedua responden II memperoleh skor presentase sebesar 16,66 \% dikatakan belum ada perubahan dari pertemuan pertama, kemudian pada pertemuan ketiga responden II mendapat nilai skor sebesar 19,44\% pada pertemuan ketiga tersebut responden II mengalami kenaikan keterampilan membaca.

Pada pemerolehan nilai keterampilan responden III pada pertemuan pertama mendapat skor dari perhitungan 24: $144 \times 100 \%=16,66 \%$, emudian pada pertemuan ketiga responden III mendapat skor perolehan sebesar 19,44 \% pada pertemuan kedua tersebut responden III meningkat dibandingkan dengan responden I dan responden II, dan pada pertemuan tiga responden III mendapat skor nilai presentasi tertinggi yaitu $22,22 \%$

Dengan demikian presentase nilai keterampilan siswa ABK dari pertemuan pertama, petermuan kedua, pertemuan ketiga mengalami peningkatan. Nilai presentase keterampilan membaca siswa ABK di tunjukkan pada tabel 4 berikut.

Tabel 4. Presentase Nilai Keterampilan Siswa ABK

\begin{tabular}{lccc}
\hline \multicolumn{1}{c}{ Pertemuan } & RA & RB & RC \\
\hline Pertemuan I & $08,33 \%$ & $16,66 \%$ & $16,66 \%$ \\
Pertemuan II & $09,22 \%$ & $16,66 \%$ & $19,44 \%$ \\
Pertemuan III & $11,11 \%$ & $19,44 \%$ & $22,22 \%$ \\
\hline
\end{tabular}

Selain dengan nilai keterampilan, perkembangan kemampuan membaca siswa ABK juga dinilai dengan penilaian kognitif dengan berupa lima soal penalaran . Berdasarkan hasil presentase menunjukan bahwa instrument soal yang telah dibuat peneliti termasuk kategori baik dan layak untuk digunakan dalam pengujian tes kepada siswa.

Analisis dari masing-masing soal dapat dilihat sebagai berikut;

1. Memahami teks cerita.

Pada soal nomor satu, dua, dan lima didapat hasil presentase sebesar 19,48\% dengan rata-rata skor 5\%. Yang artinya terdapat satu siswa dari 29 siswa yang mendapat jawaban salah, dengan acuan pada skor maksimal 20-point untuk soal tersebut, dengan kata lain sebesar 19,31\% siswa berhasil menjawab dengan benar.

2. Berpikir logis dan menarik kesimpulan.

Pada soal nomor tiga dan empat didapat hasil presentase sebesar 18,96\% dengan rata-rata skor 5\% yang berarti sebanyak 2 siswwa dari 29 siswa yang menjawab salah, dengan artian sebanyak 27 siswa menjawab benar, dengan hasil presentase sebanyak $18,67 \%$.

\section{Simpulan dan Saran}

Hasil analisis penanganan kesulitan membaca siswa ABK kelas tiga SD Negeri Poncol 03 Pekalongan sudah terlaksanakan dengan baik dan lancar dengan menggunakan metode SAS. Pada saat penelitian peran guru dan siswa mempengaruhi kegiatan pembelajaran, pada proses pengamatan guru menyampaikan materi yang mudah dipahami oleh siswa. Dari hasil kuesioner didapat hasil presentase sebesar 82,4 \%. Pada proses pembelajaran sebelum diterapkannya metode SAS ketiga siswa ABK mendapat nilai rata-rata $33,33 \%$, kemudian pada penelitian pertama sampai penelitian ketiga hasil tes keterampilan membaca siswa ABK dan tes soal penalaran menunjukan bahwa siswa ABK membutuhkan pendekatan khusus. Dengan adanya penelitian ini kemampuan membaca siswa ABK meningkat mulai dari responden I pertemuan pertama, kedua, ketiga yaitu memperoleh skor sebesar 08,33\% meningkat menjadi $09,22 \%$ meningkat lagi menjadi $11,11 \%$, pada responden II pertemuan pertama, kedua, ketiga memperoleh skor sebesar 16,66\%, dan masih memperoleh skor yang sama pada pertemuan kedua yaitu $16,66 \%$ dan meningkat menjadi 19,44\%, kemudian pada responden III pertemuan pertama, kedua, ketiga memperoleh skor sebesar $16,66 \%$ meningkat menjadi $19,44 \%$ dan meningkat lagi menjadi $22,22 \%$. Dengan hal itu penerapan metode SAS dalam peningkatan kemampuan membaca siswa ABK cocok digunakan pada SD Negeri Poncol 03 Pekalongan. 
Saran yang dapat diberikan yaitu: 1) Bagi siswa ABK, Diharapkan mampu menjadikan penelitian ini sebagai motivasi dalam mengembangkan kemampuan membaca; 2) Bagi guru, diharapkan lebih memperhatikan kemampuan membaca siswa ABK selama proses pembelajaran; 3) Bagi peneliti berikutnya diharapankan dapat lebih berinovasi dalam mengembangkan metode peneltian, instrumen yang lebih menarik serta pendukung dalam upaya peningkatan kemampuan membaca siswa ABK.

\section{Daftar Rujukan}

Chall, J. (1990). Reading and Early Childhood Education. The Critical Issues. Principal, 66(5), 6-9.

Eikeseth, S \& Nesset, R. 2003. Behavioral Threatment Of Chidern With Phonological Disorder The Efficacy of Vocal Immitation and Sufficient Response Exemplar Training. Journal Of Applied Behavior Analys 36(3), (325-337).

Eliastuti, M., \& Irwansyah, N. (2018). Keefektifan Membaca Menggunakan Metode Struktural Analitik Sintetik (SAS) pada Siswa yang Kesulitan Membaca. Deiksis, 10(01), 33. https://doi.org/10.30998/deiksis.v10i01.2265

Jamaris, M. (2014). Kesulitan Belajar: Perspektif, Asesmen, dan Penanggulangannya Bagi Anak Usia Dini dan Usia Sekolah. Ghalia Indah.

Kurniasih, I. dan B. S. (2017). Ragam Pengembangan Model Pembelajaran. Kata Pena.

Lisnawati, L., \& Muthmainah, M. (2018). Efektivitas Metode Sas (Struktur Analitik Sintetik) Dalam Meningkatkan Keterampilan Membaca Bagi Anak Lambat Belajar (Slow Learner) Di Sdn Demangan. Jurnal Psikologi Integratif, 6(1), 81. https://doi.org/10.14421/jpsi.v6i1.1468

Putri, Gocik Vidia Hapsari, M. Shodiq AM, Asim. 2018. Metode SAS (Struktural Analitik Sintetik) dalam Meningkatkan Kemampuan Membaca Permulaan bagi Siswa Tunagrahita Sedang. Jurnal Ortopedagogia, Vol. 4(1); (48-51). DOI: http://dx.doi.org/10.17977/um031v4i12018p048

Sugiarto, dkk.(2007) Psiologi Pendidikan. Yogyakarta: UNY Press

Sugiyono (2013) Metode Penelitian Pendidikan : Pendekatan Kuantitatif Kualitattif, R \& D. Bandung: Alfabeta

Susanto, Ahmad (2013).Teori Belajar dan Pembelajaran di Sekolah Dasar . Jakarta : Kencana

Ningrat, S. P., \& Sumantri, M. (2018). Kontribusi Gaya Belajar Dan Motivasi Belajar Terhadap Hasil Belajar Bahasa Indonesia Siswa. 2, 145-152.

Resmi, W. F. A. U. S. S. A. B. (2019). terhadap Kemampuan Membaca. Jurnal PGSD, 12(1), 1-8.

Tarigan, Henry Guntur.1993. Membaca Sebagai Suatu Keterampilan Berbahasa. Bandung : Angkasa

Tarigan, G. (2008). Berbicara Sebagai Suatu Keterampilan Berbahasa. Angkasa Bandung. 